Section Editor Mitchell S.V. Elkind, MD, MS
Teaching NeuroImages:

\section{Epilepsia partialis continua revealing PML after allogenic stem cell transplantation}

Daniela Andriuta, MD Mélissa Tir, MD, PhD Bertille Perin, MD

Philippe-Edouard Merle, MD

Céline Bryer-Le Breton, MD

Amandine Charbonnier, MD

Jean-Marc Constans, $\mathrm{MD}, \mathrm{PhD}$

Olivier Godefroy, MD, $\mathrm{PhD}$

Correspondence to

Dr. Andriuta: zara1986@hotmail.com

Figure 1 Scalp EEG

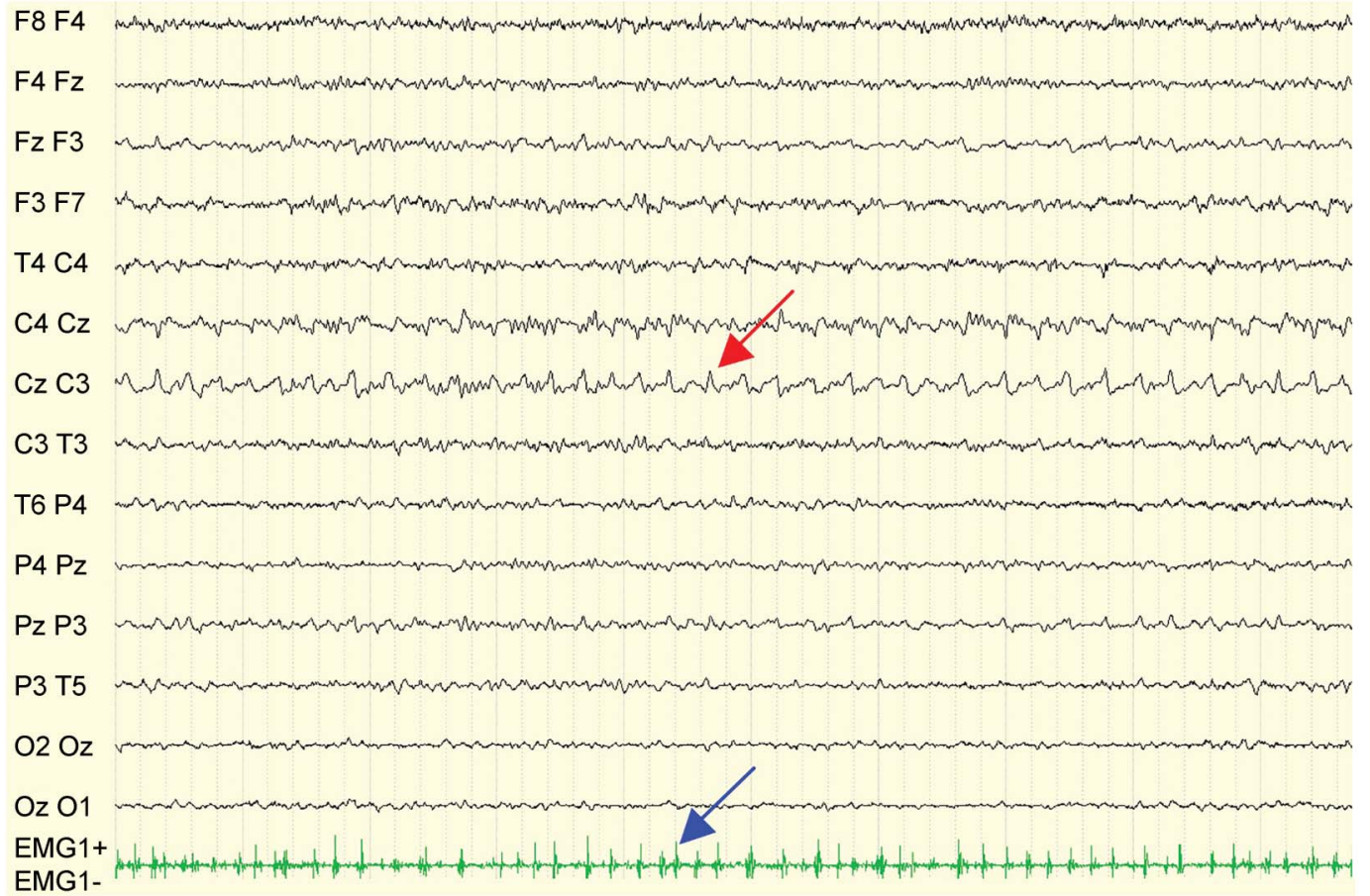

EMG1-

Continuous rhythmic sharps (red arrow) in the left rolandic derivation ( $\mathrm{Cz} C 3$ ) during right foot myoclonus (blue arrow).

A 54-year-old man, 15 months after allogenic peripheral blood stem cell transplantation (ASCT) for myelodysplasia, developed continuous right foot involuntary twitching. The EEG was suggestive of epilepsia partialis continua (EPC) (figure 1). Brain MRI showed increased signal in the left rolandic white matter (figure 2). Blood assessment found 3,400 leukocytes, 500 lymphocytes, and CSF PCR JC virus was positive $(250$ copies $/ \mathrm{mL})$ with normal cyto-biochemical assessment. This case fits diagnostic criteria of progressive multifocal leukoencephalopathy (PML). ${ }^{1}$ PML is exceptionally revealed by $\mathrm{EPC}^{2}$ and constitutes a rare complication of ASCT.

\section{AUTHOR CONTRIBUTIONS}

Daniela Andriuta: first draft manuscript writing. Mélissa Tir: review and critique of manuscript. Bertille Perin: EEG interpretation, review and critique of manuscript. Philippe-Edouard Merle: EEG interpretation, review and critique of manuscript. Céline Bryer-Le Breton: review and critique of manuscript. Amandine Charbonnier: review and critique of manuscript. Jean-Marc Constans: MRI interpretation, review and critique of manuscript. Olivier Godefroy: review and critique of manuscript.

\section{STUDY FUNDING}

No targeted funding reported.

\section{DISCLOSURE}

The authors report no disclosures relevant to the manuscript. Go to Neurology.org for full disclosures.

\section{REFERENCES}

1. Berger JR, Aksamit AJ, Clifford DB, et al. PML diagnostic criteria: consensus statement from the AAN Neuroinfectious Disease Section. Neurology 2013;80:1430-1438.

2. Lima MA, Drislane FW, Koralnik IJ. Seizures and their outcome in progressive multifocal leukoencephalopathy. Neurology 2006;66:262-264.
Download teaching slides: Neurology.org
From the Departments of Neurology (D.A., M.T., B.P., C.B.-L.B., O.G.), Neurological Electrophysiology (B.P., P.-E.M.), Clinical Hematology (A.C.), and Radiology (J.-M.C.), Amiens University Hospital, France. 
Figure 2 Cerebral MRI
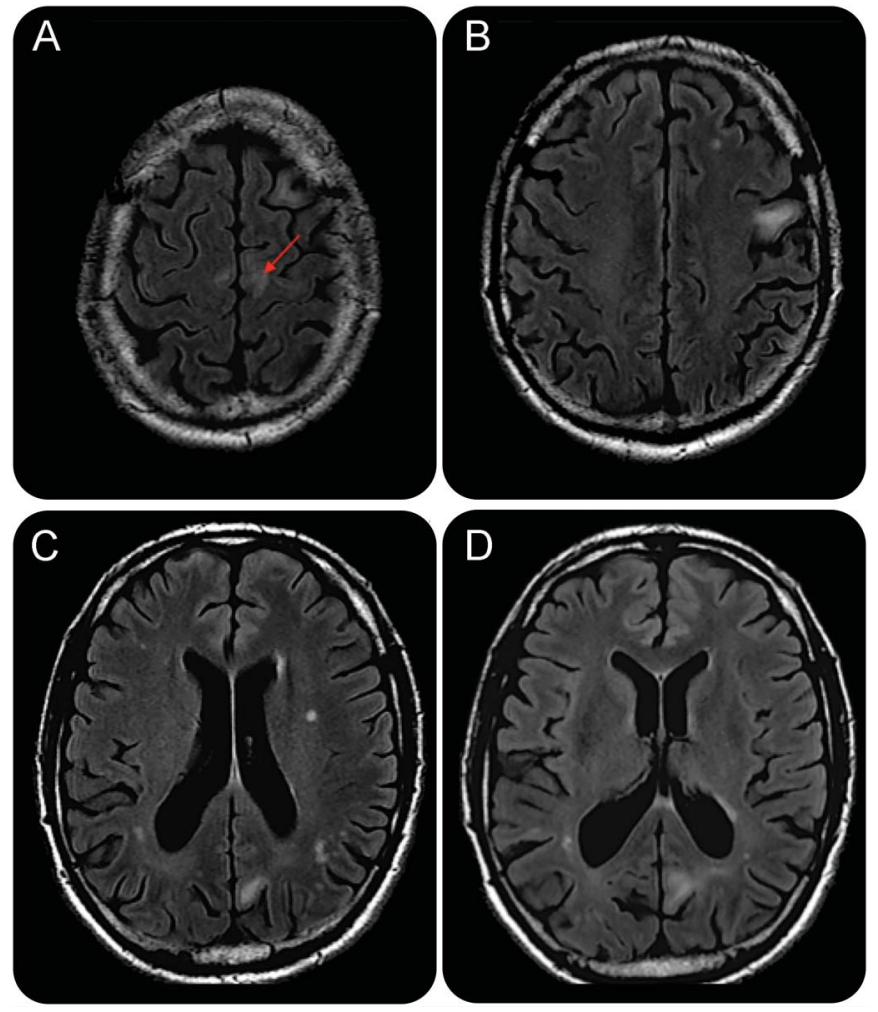

Axial fluid-attenuated inversion recovery images: (A) hyperintensity in left rolandic subcortical white matter (arrow); (B-D) multifocal asymmetric nonconfluent white matter lesions, with no mass effect. 


\section{Neurology}

\section{Teaching NeuroImages: Epilepsia partialis continua revealing PML after allogenic stem cell transplantation}

Daniela Andriuta, Mélissa Tir, Bertille Perin, et al.

Neurology 2015;85;e53-e54

DOI 10.1212/WNL.0000000000001804

This information is current as of August 3, 2015

\section{Updated Information \& \\ Services}

Supplementary Material

\section{References}

Subspecialty Collections

Permissions \& Licensing

Reprints including high resolution figures, can be found at:

http://n.neurology.org/content/85/5/e53.full

Supplementary material can be found at:

http://n.neurology.org/content/suppl/2015/07/31/WNL.0000000000001 804.DC1

This article cites 2 articles, 2 of which you can access for free at: http://n.neurology.org/content/85/5/e53.full\#ref-list-1

This article, along with others on similar topics, appears in the following collection(s):

EEG

http://n.neurology.org/cgi/collection/eeg_

EEG; see Epilepsy/Seizures

http://n.neurology.org/cgi/collection/eeg_see_epilepsy-seizures

MRI

http://n.neurology.org/cgi/collection/mri

Status epilepticus

http://n.neurology.org/cgi/collection/status_epilepticus

Viral infections

http://n.neurology.org/cgi/collection/viral_infections

Information about reproducing this article in parts (figures,tables) or in its entirety can be found online at:

http://www.neurology.org/about/about_the_journal\#permissions

Information about ordering reprints can be found online:

http://n.neurology.org/subscribers/advertise

Neurology ${ }^{\circledR}$ is the official journal of the American Academy of Neurology. Published continuously since 1951, it is now a weekly with 48 issues per year. Copyright @ 2015 American Academy of Neurology. All rights reserved. Print ISSN: 0028-3878. Online ISSN: 1526-632X.

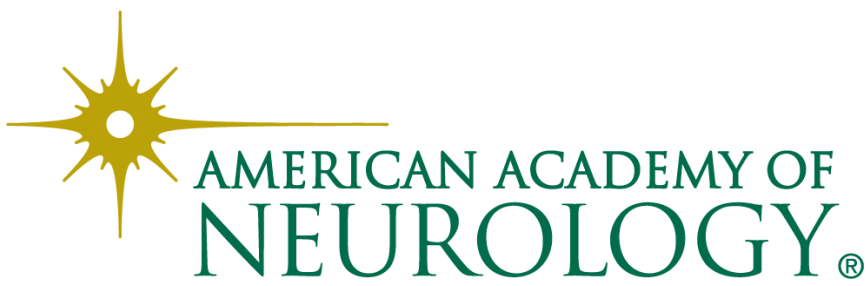

